\title{
PENGARUH LIKUIDITAS, SOLVABILITAS, PROFITABILITAS TERHADAP NILAI PERUSAHAAN PERTAMBANGAN DI BURSA EFEK INDONESIA
}

\author{
Neti Erlina \\ Sekolah Tinggi Ilmu Ekonomi Rahmaniyah \\ Email: netierlina1981@gmail.com
}

\begin{abstract}
Effect of liquidity, solvency, profitability against mining company value in indonesian stock exchange (BEI).purpose to determine the effect of liquidity, solvency, profitability of the value mining company in indonesian stock exchange (BEI). the data used in this research is the data time series, a variabel which is used liquidity Current Ratio, Cash Ratio, Solvency Debt To Equity Ratio, Debt To Aset Ratio, profitability Net Profit Margin, Earning Pershare again the study population valueof the company is amining company listed on the indonesian stock exchange period 2009-2013. The technique of taking sample uses purposive sampling and obtained 14companies were selected as sample.the analysis technique used in this researchis to test assumtions of linear regression. including normality test heterokedastisitas test, multicolinearity test, autocorrelation test, test the hypothesis that the $F$ test and $t$ test.fidding indicates that the variable liquidity (Current Rasio X1,Cash Rasio X2), solvency (Debt To Asset Ratio X3, Debt To Equity Ratio X4), profitability Net Profit Margin (X5),Earning Pershare (X6) on mining company indonesian stock exchange shows influence significant together against the value of company.partial Current Rasio (X1),Cash Rasio (X2), Debt To Asset Ratio (X3), Debt To Equity Ratio (X4), Net Profit Margin (X5),Earning Pershare (X6)had no significant effect on firm value.
\end{abstract}

Keywords: Liquidity, Solvency, Profitability

\section{PENDAHULUAN}

Persaingan dunia usaha maupun bisnis yang semakin ketat dan global, situasi ekonomi yang tidak menentu saat ini membuat perusahaan harus memiliki kemampuan untuk bertahan. Upaya yang harus dilakukan dengan menerapkan berbagai kebijakan strategi yang menghasilkan efisiensi dan efektifitas bagi perusahaan. tentu saja hal tersebut memberikan modal yang cukup besar bagi perusahaan yang meliputi usaha untuk memperoleh dana tersebut dan mengalokasikannya dengan optimal. Secara umum nilai suatu perusahaan adalah gambaran kondisi perusahaan, apakah perusahaan dalam keadaan baik atau tidak.

Nilai perusahaan merupakan harga yang harus dibayar oleh calon pembeli jika perusahaan tersebut dijual. karena nilai perusahaan dapat memberikan kemakmuran yang maksimal bagi pemegang saham secara maksimum apabila harga saham meningkat. Kemajuan dunia usaha dewasa ini berkembang dengan pesat disektor industri sehingga investor dapat mengalokasikan dana yang dimiliki dengan lebih baik baik melalui investasi dipasar uang, pasar modal, dan pasar turunan. Investasi dipasar modal merupakan salah satu investasi yang diminati oleh investor. Investor yang melakukan investasi harus dapat melakukan penilaian dengan baik terhadap perusahaan yang ingin diinvestasikannya. (Ganto, dkk. 2008). 
Pertimbangan utama investor dalam membuat keputusan berinvestasi dilihat dari kinerja yang baik suatu perusahaan, dengan Analisis laporan keuangan merupakan proses yang penuh pertimbangan dalam rangka membantu mengevaluasi posisi keuangan perusahaan dengan baik tujuannya untuk menentukan dan memprediksi yang paling mungkin mengenai kondisi dan kinerja perusahaan itu sendiri. laporan keuangan perusahaan dianalisa dari tingkat profitabilitas, tingkat solvabilitas, dan likuiditas suatu perusahaan dalam menilai prestasi manajemen dimasa lalu dan prospeknya dimasa yang akan datang. (Sutrisno, 2009).

Nilai Perusahaan yang meningkat dalam hal ini akan mempengaruhi kemakmuran para pemegang saham secara maxsimum apabila harga saham meningkat, semakin tinggi harga saham suatu perusahaan maka semakin tinggi tingkat kemakmuran pemegang saham, Eterprise Value (EV) atau dikenal firm Value (Nilai Perusahaan) karena indikator bagi pasar menilai perusahaan secara keseluruhan dapat dilihat dari kinerja perusahaan itu sendiri (Jogiyanto,2010). Nilai suatu perusahaan dapat dilihat dari kinerja perusahaaan itu sendiri. Kinerja perusahaan diukur dengan rasio rasio keuangan, rasio keuangan tersebut adalah Likuiditas yang diukur dengan Current Ratio dan Cash Ratio, Solvabilitas yang diukur dengan Debt to Asset Ratio dan Debt to Equity Ratio, Profitabilitas yang diukur dengan Net Profit Margin dan Earning Persahare.

Likuiditas merupakan rasio yang digunakan untuk mengukur tingkat kemampuan suatu perusahaan dalam memenuhi kewajiban keuangan berjangka pendek tepat pada waktunya. tingkat likuiditas yang tinggi akan memperkecil kegagalan perusahaan dalam memenuhi kewajiban finansial jangka pendek pada kreditur. tinggi rendahnya rasio ini akan mempengaruhi minat investor untuk menginvestasikan dananya.

Solvabilitas menggambarkan persentase dana perusahaan yang berasal dari pinjaman investor dan kreditor, (Kuswandi 2005). Pihak manajemen harus mampu menjaga tingkat solvabilitas agar para kreditor dapat mempercayai suatu perusahaan dalam mengelola sumber pendanaannya. Profitabilitas menghubungkan laba dari penjualan dan investasi, sehingga dapat diketahui bagaimana tingkat profitabilitas suatu perusahaan dapat berada dalam keadaan yang menguntungkan (Profitable).

Rasio Keuangan tersebut digunakan investor untuk mengetahui nilai pasar perusahaan, dan dapat memberikan indikasi bagi manajemen mengenai penilaian investor terhadap kinerja perusahaan dengan tujuan memberikan gambaran mengenai kelemahan dan kemampuan finansial perusahaan dari tahun ke tahun. Analisis rasio ini sangat membantu dalam menilai prestasi manajemen dimasa lampau dan prospeknya di masa depan. Menurut penelitian Mahendra, dkk. (2012) kinerja keuangan yang diproksikan melalui Return on Equity berpengaruh positif pada nilai perusahaan, semakin tinggi Return on Equity, maka perusahaan dapat menghasilkan keuntungan yang tinggi bagi pemegang saham dan meningkatkan nilai perusahaan.

\section{Perumusan masalah}

Bagaimana Pengaruh Likuiditas, Solvabilitas, Profitabilitas terhadap Nilai Perusahaan Pertambangan di Bursa Efek Indonesia.

\section{Tujuan Penelitian}

Untuk Mengetahui Pengaruh Likuiditas, Solvabilitas, Profitabilitas terhadap Nilai Perusahaan Pertambangan di Bursa Efek Indonesia.

\section{Manfaat}

Penelitian ini diharapkan dapat menjadi acuan bagi investor dalam pengambilan keputusan untuk berinvestasi dipasar modal khususnya instrument saham perusahaan pertambangan. Dengan menganalisis pengaruh Likuiditas, Solvabilitas, Profitabilitas terhadap nilai perusahaan diharapkan bermanfaat untuk memprediksi pendapatan dividen para pemegang saham. 


\section{KAJIAN PUSTAKA}

\section{Nilai Perusahaan}

Perusahaan adalah suatu organisasi yang mengkombinasikan dan mengoorganisasikan berbagai sumber daya dengan tujuan untuk memproduksi barang dan jasa untuk dijual Salvatore (2010) perusahaan menjadi tidak efisien dan mahal bagi penguasa untuk masuk dan membuat kontrak dengan pekerja dan para pemilik modal, tanah dan sumber daya lain untuk setiap tahap produksi dan distribusi yang terpisah. Penguasa masuk kedalam kontrak yang besar dan berjangka panjang dengan tenaga kerja untuk mengerjakan berbagai tugas dan upah tertentu dengan berbagai tunjangan lain.

\section{Likuiditas}

Rasio Likuiditas ini sering digunakan oleh perusahaan maupun investor untuk mengetahui tingkat kemampuan perusahaan dalam memenuhi kewajibannya (Kasmir 2012). Kewajiban tersebut bersifat jangka pendek. Kewajiban jangka pendek itu seperti, membayar tagihan listrik, gaji pegawai, atau hutang yang telah jatuh tempo. tetapi terkadang ada beberapa perusahaan tidak sanggup membayar hutang tersebut pada waktu yang telah ditentukan, dengan alasan perusahaan tidak memiliki dana yang cukup untuk menutupi hutang yang telah jatuh tempo tersebut. Kasus tersebut akan mengganggu hubungan antara perusahaan dengan para kreditor, maupun para distributor. dalam jangka panjang kasus tersebut akan berdampak kepada para pelanggan. artinya pada akhirnya perusahaan akan mengalami krisis ekonomi. Hal tersebut dikarenakan perusahaan tidak memperoleh kepercayaan dari pelanggan.

Brigham dan Houston dalam bukunya "Dasar- dasar Manajemen Keuangan" (2006), mengatakan bahwa:asset likuid merupakan asset yang diperdagangkan di pasar aktif sehingga dapat dikonversi dengan cepat menjadi kas pada harga pasar yang berlaku, sedangkan posisi likuiditas suatu perusahaan berkaitan dengan pertanyaan, apakah perusahaan mampu melunasi utangnya ketika utang tersebut jatuh tempo di tahun berikutnya.

\section{Solvabilitas}

Kemampuan perusahaan untuk memenuhi semua kewajibannya apabila perusahaan dilikuidasi. Biasanya permasalahan yang akan muncul apabila perusahaan ditutup menyangkut apakah kekayaan yang dimiliki perusahaan mampu menutup semua hutang-hutangnya. Apabila perusahaan mampu menutupi semua hutangnya maka perusahaan dalam kondisi solvabel. Sebaiknya apabila perusahaan dilikuidasi perusahaan tidak bisa menutup semua hutang-hutannya berarti perusahaan dalam kondisi insolvabel. Untuk menutup semua hutangnya maka perusahaan menjamin dengan semua kekayaannya (Asset). Dengan demikian solvabilitas perusahaan dapat dihitung dengan cara membagi total asset dengan total hutang (Sutrisno, 2009).

\section{Profitabilitas}

Profitabilitas adalah kemampuan perusahaan untuk menghasilkan laba dan memanfaatkan aset tetap yang digunakan untuk beroperasi. Mamduh (2005) mengungkapkan bahwa rasio profitabilitas dan rasio rentabilitas menunjukkan keberhasilan perusahaan dalam menghasilkan keuntungan. Kemampuan perusahaan untuk menghasilkan laba dalam kegiatan operasinya merupakan fokus utama dalam penilaian prestasi perusahaan. Selain merupakan indikator kemampuan perusahaan dalam memenuhi kewajiban bagi para penyandang dananya, laba perusahaan juga merupakan elemen dalam menentukan nilai perusahaan. Efektivitas dinilai dengan menghubungkan laba bersih yang didefinisikan dalam berbagai rasio terhadap aktiva, misalnya rasio profitabilitas. 


\section{METODE PENELITIAN}

\section{Operasional Variabel}

Metode Penelitian yang dilakukan adalah penelitian asosiatif, yaitu penelitian yang bertujuan menganalisis hubungan antara satu variabel dengan variabel lainnya, atau bagaimana suatu variabel mempengaruhi variabel lain (Sugiyono, 2011) penelitian ini untuk membuktikan secara empiris tentang pengaruh suatu variabel terhadap variabel lain yaitu pengaruh Likuiditas, Solvabilitas, Profitabilitas terhadap nilai perusahaan pertambangan di Bursa Efek Indonesia. Dimana variabel indevenden yaitu Likuiditas (Current Rasio, Cash Ratio), Solvabilitas (Debt To Equity Ratio, Debt To Asset Ratio), Profitabilias (Net Profit Margin, Earning Pershare) (X) dan variabel devenden yaitu Nilai Perusahaan Pertambangan di Bursa Efek Indonesia (Y) didapatkan melalui laporan keuangan Perusahaan Pertambangan Bursa Efek Indonesia.

Desain penelitian yang digunakan dalam penelitian ini adalah kuantitatif korelasional. Penelitian Kuantitatif Korelasional adalah penelitian yang bekerja dengan angka, yang datanya berwujud bilangan yang di analisis penelitian yang sifatnya spesifik untuk melakukan prediksi bahwa suatu variabel tertentu mempangaruhi variabel lain.

Berikut ini disajikan Operasional Variabel dapat dilihat pada Tabel 1.

Tabel 1

Operasional Variabel

\begin{tabular}{|c|c|c|c|c|}
\hline Variabel & Definisi Variabel & Dimensi & Indikator & Skala \\
\hline Likuiditas & $\begin{array}{l}\text { kewajiban perusahaan untuk memenuhi } \\
\text { kewajiban kewajibannya yang segera } \\
\text { dipenuhi. Atau memenuhi Kewajiban } \\
\text { jangka Pendeknya perusahaan ditunjukkan } \\
\text { oleh besar kecilnya aset lancar atau aset } \\
\text { yang mudah dijadikan uang, seperti kas, } \\
\text { surat berharga, piutang, dan persediaan } \\
\text { Sutrisno (2009). }\end{array}$ & $\begin{array}{l}\text { - Current Ratio } \\
\text { - Cash Ratio }\end{array}$ & $\begin{array}{l}\text {-Aset Lancar/ } \\
\text {-Hutang Lancar } \\
\text { - Kas/ } \\
\text {-HutangLancar }\end{array}$ & Rasio \\
\hline Solvabilitas & $\begin{array}{l}\text { kemampuan perusahaan untuk memenuhi } \\
\text { semua kewajibannya apabila perusahaan } \\
\text { dilikuidasi atau menunjukkan adanya dana } \\
\text { dari pihak luar. dengan demikian } \\
\text { solvabilitas perusahaan dapat dihitung } \\
\text { dengan cara membagi total aset dengan total } \\
\text { hutang. Sutrisno (2009) }\end{array}$ & $\begin{array}{l}\text {-Debt To Equity Ratio } \\
\text {-Deb toAset Ratio }\end{array}$ & $\begin{array}{l}\text {-Total Aset/ } \\
\text {-Total Hutang } \\
\text {-Total Hutang } \\
\text {-Total Aset }\end{array}$ & Rasio \\
\hline Profitabilitas & $\begin{array}{lll}\text { Kemampuan } & \text { perusahaan } & \text { dalam } \\
\text { menghasilkan laba. Sutrisno (2009) } & \end{array}$ & $\begin{array}{l}\text { - Net Profit Margin } \\
\text {-Earning Per Share }\end{array}$ & $\begin{array}{l}\text {-Laba Bersih } \\
\text { Setelah Pajak/ } \\
\text {-Penjualan } \\
\text {-Laba Bersih } \\
\text { Setelah Pajak/ } \\
\text {-Jumlah Saham }\end{array}$ & Rasio \\
\hline Nilai Perusahaan & $\begin{array}{l}\text { Merupakan Indikator bagi pasar yang } \\
\text { menilai perusahaan secara keseluruhan } \\
\text { dilihat dari kinerja itu sendiri, nilai pasar } \\
\text { yang meningkat akan mempengaruhi para } \\
\text { pemegang saham. (Jogiyanto, 2010) }\end{array}$ & -Nilai Buku Saham & $\begin{array}{l}\text {-HargaPasar } \\
\text { Saham/ } \\
\text {-Harga Buku } \\
\text { Saham }\end{array}$ & Rasio \\
\hline
\end{tabular}

Data

Jenis data yang digunakan dalam penelitian ini adalah data time series yaitu data yang terdiri dari data objek beberapa periode tertentu. Sumber data yang digunakan dalam penelitian ini adalah data sekunder, yaitu sumber data penelitian diperoleh peneliti secara tidak lansung melalui media perantara diperoleh dan dicatat dari pihak lain berupa bukti catatan atau laporan historis yang telah tersusun dalam arsip data dokumentar yang di publikasikan dan tidak dipublikasikan (Sugiyono, 2009) data yang diperoleh dari laporan-laporan tahunan perusahaan, dan sustainability report dan didapatkan melalui Indonesian Capital Market Directory 2012dan Indonesian Capital Market Directory 2014 dan website Resmi Perusahaan Pertambangan yang terdaftar di BEI dari tahun 2009 sampai 2013. 
Variabel

Variabel penelitian digunakan sebagai padanan untuk konstruk atau sifat yang sedang diteliti (Cooper dan Schindler, 2006). Penelitian ini menggunakan variabel bebas dan variabel terikat. Variabel bebas (Independen) yaitu: Likuiditas, Solvabilitas, Profitabilitas yang diproksikan melalui Likuiditas (Current Rasio, Cash Ratio), Solvabilitas (Debt To Equity Ratio, Debt To Asset Ratio), Profitabilias (Net Profit Margin, Earning Pershare) variabel terikat (Dependen) yaitu nilai perusahaan yang diproksikan melalui rasio Tobin'Q yaitu nilai saham perusahaan.

1. Variabel Bebas (Independen)

Pengukuran Kinerja Keuangan di ukur dengan rasio sebagai berikut:

Rasio Likuiditas

Likuiditas perusahaan ditunjukkan oleh besar kecilnya aset lancar atau aset yang mudah dijadikan uang, seperti kas, surat berharga, piutang, dan persediaan (Sutrisno, 2009). Digunakan rumus sebagai berikut:

Current Ratio $=\frac{\text { Aset Lancar }}{\text { Hutang Lancar }} \times 100 \%$
Cash Ratio $=\frac{\text { Kas }}{\text { Hutang Lancar }} \times 100 \%$

Rasio Solvabilitas

$D E R=\frac{\text { Total Aset }}{\text { Total Hutang }}$
$D A R=\frac{\text { Total Hutang }}{\text { Total Aset }}$

\section{Rasio Profitabilitas}

Brigham, (2006) Mengatakan Net Profit Margin, diukur dengan cara membagi laba setelah bunga dan pajak dengan penjualan net profit margin yang tinggi menandakan kemampuan perusahaan menghasilkan laba yang tinggi pada tingkat penjualan tertentu

$$
\mathrm{NPM}=\frac{\text { Laba Bersih Setelah Pajak }}{\text { Penjualan }} \times 100 \%
$$

Van Horne, (2007)Mengatakan Earning Pershare diukur dengan membagi laba saham biasa dan jumlah saham biasa yang beredar.

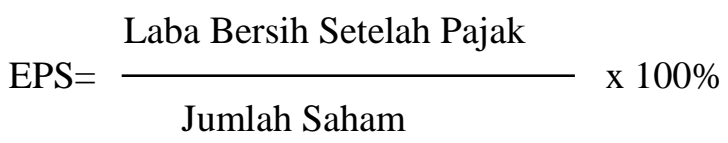

\section{Variabel Terikat (Dependen)}

Variabel terikat adalah variabel yang diharapkan peneliti dapat dipengaruhi oleh variabel bebas (Cooper dan Schindler, 2006). Penelitian ini menggunakan nilai perusahaan sebagai variabel terikat, dimana nilai perusahaan merupakan harga yang akan dibayarkan oleh calon pembeli apabila perusahaan tersebut dijual yaitu nilai saham digunakan sebagai proksi dari nilai perusahaan. Rasio Tobin's Q dikembangkan oleh profesor James Tobin. Rasio Tobin's Q menunjukkan estimasi pasar keuangan 
saat ini tentang nilai hasil pengembalian dari setiap investasi inkremental. mengukur nilai perusahaan dengan rasio Tobin's $\mathrm{Q}$ dirumuskan sebagai berikut:

$$
\mathrm{PBV}=\frac{\text { Nilai Pasar Equitas }}{\text { Nilai Buku Equitas }}
$$

\section{Populasi Dan Sampel}

Populasi adalah wilayah generalisasi yang terdiri atas obyek/subyek yang mempunyai kualitas dan karakteristik tertentu yang ditetapkan oleh peneliti untuk dipelajari dan kemudian ditarik kesimpulannya Sugiyono, (2011).

Populasi dalam penelitian ini adalah perusahaan pertambangan Bursa Efek Indonesia, sesuai dengan laporan keuangan yang dipublikasi Indonesia Capital Market Directory 2014 dan Indonesia Capital Market Directory 2012. Jumlah perusahaan pertambangan yang terdaftar di Bursa Efek Indonesia tahun 2014 sejumlah 22 emiten yang memiliki kegiatan aksplorasi, penambangan, pengolahan serta pemasaran sumber daya dan mineral.

Berikut ini disajikan Populasi penelitian pada perusahaan pertambangan di Bursa Efek Indonesia tahun 2014, dapat dilihat pada Tabel 2.

\section{Tabel 2}

\begin{tabular}{|c|c|c|c|}
\hline NO. & NAMA SAHAM & NAMA EMITEN & TANGGAL PENDAFTARAN \\
\hline 1. & ADRO & Adaro Energi Tbk & 16 Juli 2008 \\
\hline 2. & ARII & Atlas Resources Tbk & 8 November 2011 \\
\hline 3. & ATPK & ATPK Resources Tbk & 17 April 2002 \\
\hline 4. & BORN & Bomeo Lumbung Energy\& Metal Tbk & 26 November 2010 \\
\hline 5. & BRAU & Berau Coal Energy Tbk & 19 Agustus 2010 \\
\hline 6 & BSSR & Baramulti Suksessarana Tbk & 8 November 2002 \\
\hline 7. & BUMI & Bumi Resources Tbk & 30 Juli 1990 \\
\hline 8. & BYAN & Bayan Resources Tbk & 12 Agustus 2008 \\
\hline 9. & DEWA & Darma Henwa Tbk & 26 September 2007 \\
\hline 10. & DOID & Delta Dunia Makmur & 15 Juni 2001 \\
\hline 11. & GEMS & Golden Energy mines Tbk & 17 November 2011 \\
\hline 12. & GTBO & Garda Tujuh Buana Tbk & 18 Desember 2007 \\
\hline 13. & HRUM & Harum Energy Tbk & 06 Oktober 2010 \\
\hline 14. & ITMG & Indo Tambang Raya Mega Tbk & 18 Desember 2007 \\
\hline 15. & KKGI & Resource Alam Indonesia Tbk & 1 Juli 1991 \\
\hline 16. & MBAP & Mitrabara Adiperdana Tbk & 10 Juli 2014 \\
\hline 17. & MYOH & Samindo Resources Tbk & 27 Juli 2000 \\
\hline 18. & PKPK & Perdana Karya Perkasa Tbk & 11 Juli 2007 \\
\hline 19. & PTBA & Tambang Batubara Bukit Asam (Persero) Tbk & 23 Desember 2002 \\
\hline 20. & PTRO & Petrosea Tbk & 21 Mei 1990 \\
\hline 21. & SMMT & Golden Eagle Energy Tbk & 29 Februari 2000 \\
\hline 22. & TOBA & Toba Bara Sejahtera Tbk & 6 Juli 2012 \\
\hline
\end{tabular}

Populasi Penelitian

Sumber: Bursa Efek Indonesia tahun 2014

Sampel adalah himpunan bagian dari jumlah dan karakteristik suatu populasi. Metode pengambilan sampel yang digunakan adalah non probability sampling2 dengan teknik purposive sampling. Menurut Sugiyono (2011), sampel adalah bagian dari jumlah dan karakteristik yang dimiliki oleh populasi.

Teknik sampling diperlukan dalam sebuah penelitian karena hal ini digunakan untuk menentukan siapa saja anggota dari populasi yang hendak dijadikan sampel. sampel sengaja diambil karena memenuhi kriteria tertentu sesuai dengan penelitian ini.

Kriteria yang digunakan dalam menentukan sampel penelitian ini adalah:

1. Perusahaan yang terdaftar diBursa Efek Indonesia dibawah tahun 2009

2. Perusahaan yang menyajikan laporan keuangan setiap tahun, selama tahun pengamatan 2009-2013 sebanyak 14 perusahaan.

3. Adanya informasi tentang nilai perusahaan. 
Berikut disajikan Populasi Penelitian pada perusahaan pertambangan diBursa Efek Indonesia tahun 2014 dapat dilihat pada Tabel 3.

Tabel 3

Sampel Penelitian

\begin{tabular}{|c|c|c|c|}
\hline NO. & NAMA SAHAM & NAMA EMITEN & TANGGAL PENDAFTARAN \\
\hline 1. & ADRO & Adaro Energi Tbk & 16 Juli 2008 \\
\hline 2. & ATPK & ATPK Resources Tbk & 17 April 2002 \\
\hline 3. & BUMI & Bumi Resources Tbk & 30 Juli 1990 \\
\hline 4. & BYAN & Bayan Resources Tbk & 13 Agustus 2008 \\
\hline 5. & DEWA & Darma Henwa Tbk & 26 September 2007 \\
\hline 6 & DOID & Delta Dunia Makmur & 15 Juni 2001 \\
\hline 7. & GTBO & Garda Tujuh Buana Tbk & 18 Desember 2007 \\
\hline 8. & ITMG & Indo Tambang Raya Mega Tbk & 18 Desember 2007 \\
\hline 9. & KKGI & Resource Alam Indonesia Tbk & 1 Juli 1991 \\
\hline 10. & $\mathrm{MYOH}$ & Samindo Resources Tbk & 27 Juli 2000 \\
\hline 11. & PKPK & Perdana Karya Perkasa Tbk & 11 Juli 2007 \\
\hline 12. & PTBA & Tambang Batubara Bukit Asam (Persero) Tbk & 23 Desember 2002 \\
\hline 13. & PTRO & Petrosea Tbk & 21 Mei 1990 \\
\hline 14. & SMMT & Golden Eagle Energy Tbk & 29 Februari 2000 \\
\hline
\end{tabular}

\section{HASIL DAN PEMBAHASAN \\ Deskriptif Statistik Data}

Tabel 4

Analisis Deskriptif

Descriptive Statistics

\begin{tabular}{|l|c|c|c|c|c|}
\hline & $\mathrm{N}$ & Minimum & Maximum & Mean & Std. Deviation \\
\cline { 2 - 6 } & Statistic & Statistic & Statistic & Statistic & Statistic \\
\hline CAR & 70 &, 02 & 49,11 & 3,1844 & 7,46753 \\
CR & 70 &, 01 & 28,10 & 1,4801 & 3,98465 \\
DER & 70 &, 08 & 55,16 & 2,8020 & 7,73019 \\
DAR & 70 &, 07 & 17,00 &, 9269 & 2,06359 \\
NPM & 70 &, 00 & 311,70 & 6,7199 & 37,49331 \\
EPS & 70 &, 01 & 985,00 & 68,0376 & 183,08871 \\
NP & 70 &, 29 & 1225,00 & 55,1389 & 206,33944 \\
Valid N & 70 & & & & \\
(listwise) & & & & & \\
\hline
\end{tabular}

Statistik Deskriptif memberikan gambaran umum tentang objek penelitian yang dijadikan sampel. Penjelasan data melalui Statistik Deskriptif diharapkan memberikan gambaran awal tentang masalah yang diteliti. Statistik Deskriptif difokuskan pada nilai maxsimum, minimum, rata-rata dan standar deviasi.

Likuiditas diukur dengan Current Ratio dan Cash Ratio. Current Ratio dengan nilai rata-rata 3,1844 persen dengan standar deviasi 7,46753 persen, nilai minimum 0,02 persen dengan maxsimum sebesar 49,11 persen, dimana nilai standar deviasi lebih besar dari pada nilai rata-rata. Cash Ratio dengan nilai rata rata 1,4801 persen, sedangkan standar deviasi sebesar 3,98456 persen, nilai minium 0,01 persen dengan maxsimum sebesar 49, 11 persen nilai standar deviasi Current Ratio dan Cash Ratio menunjukkan lebih besar dari nilai rata rata.

Solvabilitas yang diukur dengan Debt To Equity Ratio dan Debt To AssetRatio. Debt To Equity Ratio dengan rata rata 2,8020 persen dengan standar deviasi 7,73019 persen, nilai minimum 0,08 peersen dengan maxsimum sebesar 55,11 persen. Debt To Asset Ratio dengan nilai rata rata 0,9269 persen, sedangkan standar deviasi sebesar 2,06359 persen, nilai minimum 17,00 persen nilai standar deviasi menunjukkan lebih besar dari nilai rata rata.

Profitabilitas yang di ukur dangan Net Profit Margin dan Earning Pershare.Net Profit Margin dengan nilai rata rata 6,7199 persen dengan standar deviasi 37,49331 persen, nilai minimum 0,00 persen dengan maxsimum sebesar 3117,70 dan Earning 
Pershare dengan nilai rata rata 68,0376 persen, sedangkan standar deviasi sebesar 183,08871, Net Profit Margin dan Earning Pershare menunjukkan nilai standar deviasi lebih besar dari nilai rata rata.

Nilai perusahaan dengan nilai rata rata 55,1389 persen dengan standar deviasi 206,33944 persen, nilai minimum 0,29 persen dengan maxsimum sebesar 1225,00. Nilai standar deviasi lebih besar dari nilai rata rata.

\section{Uji Data}

Berikut ini hasil uji kolmogorov smirnov pada tabel yang akan diamati, disajikan pada Tabel 5.

Tabel 5

Uji Normalitas

One Sample Kolmogorov-Smirnov Test

\begin{tabular}{|c|c|c|c|c|c|}
\hline \multicolumn{3}{|c|}{ Kolmogorov-Smirnov $^{\mathrm{a}}$} & \multicolumn{3}{|c|}{ Shapiro-Wilk } \\
\hline Statistic & df & Sig. & Statistic & df & Sig. \\
\hline, 387 & 70 &, 000 &, 301 & 70 &, 000 \\
\hline ,372 & 70 & ,000 & ,346 & 70 & 000 \\
\hline ,402 & 70 & ,000 &, 322 & 70 &, 000 \\
\hline, 375 & 70 &, 000 & ,284 & 70 & ,000 \\
\hline ,429 & 70 &, 000 &, 161 & 70 &, 000 \\
\hline, 382 & 70 & ,000 &, 421 & 70 & ,000 \\
\hline 461 & 70 &, 000 &, 282 & 70 &, 000 \\
\hline
\end{tabular}

\section{Model Analisis}

a). Regresi Linier Berganda

Pengujian terhadap hipotesis penelitian ini menggunakan analisis Regresi berganda digunakan untuk menguji pengaruh beberapa variabel indevenden yaitu Current Ratio X1 dan Cash RatioX2, Debt To Equity Ratio X3, Debt To Aset RatioX4, Net Profit Margin X5 dan Earning Pershare X6.Variabel Devenden yaitu Nilai Perusahaan Pertambangan (Y). Hasil data SPSS di tampilkan dalam Tabel 6.

\section{Tabel 6}

Uji Regresi Berganda

\begin{tabular}{|c|c|c|c|c|c|c|}
\hline & \multirow[b]{2}{*}{ Model } & \multicolumn{2}{|c|}{ Unstandardized Coefficients } & \multirow{2}{*}{$\begin{array}{c}\begin{array}{c}\text { Standardized } \\
\text { Coefficients }\end{array} \\
\text { Beta }\end{array}$} & \multirow[b]{2}{*}{ t } & \multirow[b]{2}{*}{ Sig. } \\
\hline & & $\mathbf{B}$ & Std. Error & & & \\
\hline \multirow[t]{7}{*}{1} & (Constant) & 77,395 & 35,423 & & 2,185 &, 033 \\
\hline & CAR & $-1,146$ & 3,468 &,- 041 &,- 331 & ,742 \\
\hline & CR & $-1,699$ & 6,523 &,- 033 & -260 & ,795 \\
\hline & DER &,- 487 & 3,353 &,- 018 & -145 & 885 \\
\hline & DAR & $-7,257$ & 12,536 &,- 073 &,- 579 & ,565 \\
\hline & NPM & -236 & 691 &,- 043 &,- 341 & ,734 \\
\hline & EPS &,- 094 &, 142 &,- 084 &,- 664 &, 509 \\
\hline
\end{tabular}

Pada Tabel 6 hasil regresi berganda dengan menggunakan bantuan program SPSS dapat dibuat persamaan regresi berganda seperti dibawah ini:

$$
\begin{gathered}
Y=b_{0}+b_{1} X_{1}+b_{2} X_{2}+b_{3} X_{3}+b_{4} X_{4}+b_{5} X_{5}+b_{6} X_{6}-e \\
Y=77,395-1,146 X_{1}-1,699 X_{2}-0,487 X_{3}-7,257 X_{4}-0,236 X_{5}-0,094 X_{6}+e
\end{gathered}
$$

\section{Uji Model}

a. Uji Heterokedastisitas

Uji heteroskedastisitas bertujuan untuk menguji apakah dalam model regresi terjadi ketidaksamaan varian dari residual satu pengamatan kepengamatan lain 
(Ghozali, 2012). Berikut ini adalah tabel statistik yang akan diamati disajikan pada Tabel 7.

Tabel 7

Uji heterokedastisitas

Coefficients $^{\mathrm{a}}$

\begin{tabular}{|c|c|c|c|c|c|c|}
\hline \multirow{2}{*}{\multicolumn{2}{|c|}{ Model }} & \multicolumn{2}{|c|}{ Unstandardized Coefficients } & \multirow{2}{*}{$\begin{array}{c}\text { Standardized Coefficients } \\
\text { Beta }\end{array}$} & \multirow[b]{2}{*}{$\mathbf{t}$} & \multirow[b]{2}{*}{ Sig. } \\
\hline & & B & Std. Error & & & \\
\hline \multirow[t]{7}{*}{1} & (Constant) & 3405,466 & 42105,027 & &, 081 & ,936 \\
\hline & LNCAR & 11929,422 & 21884,840 & 069 &, 545 & ,588 \\
\hline & LNCR & 14015,999 & 16755,087 &, 110 &, 837 & ,406 \\
\hline & LNDER & 3738,420 & 21443,993 &, 023 &, 174 & 862 \\
\hline & LNDAR & $-53738,799$ & 37296,029 &,- 204 & $-1,441$ &, 155 \\
\hline & LNNPM & $-8896,967$ & 11680,626 &,- 098 &,- 762 & ,449 \\
\hline & LNEPS & 477,367 & 8827,998 & ,007 &, 054 & 957 \\
\hline
\end{tabular}

\section{1). Current Ratio}

Uji Heterokedastisitas ini dapat dilihat dari nilai signifikansi yang diperoleh, diketahui nilai signifikansi Current Ratio $=0,588$ lebih besar dari $(\alpha)=0,05$ hal ini berari bahwa Variabel Current Ratio tidak terjadi heterokedastisitas.

\section{2).Cash Ratio}

Uji Heterokedastisitas ini dapat dilihat dari nilai signifikansi yang diperoleh, diketahui nilai signifikansi Cash Ratio $=0,406$ lebih besar dari $(\alpha)=0,05$ hal ini berari bahwa Variabel Cash Ratio tidak terjadi heterokedastisitas.

\section{3).Debt to Equity Ratio}

Uji Heterokedastisitas ini dapat dilihat dari nilai signifikansi yang diperoleh, diketahui nilai signifikansi Debt to Equity Ratio $=0,862$ lebih besar dari $(\alpha)=0,05$ hal ini berari bahwa Debt to Equity Ratio tidak terjadi heterokedastisitas.

\section{4).Debt to Asset Ratio}

Uji Heterokedastisitas ini dapat dilihat dari nilai signifikansi yang diperoleh, diketahui nilai signifikansi Debt to Asset Ratio $=0,155$ lebih besar dari $(\alpha)=0,05$ hal ini berari bahwa Debt to Asset Ratio tidak terjadi heterokedastisitas.

\section{5).Net Profit Margin}

Uji Heterokedastisitas ini dapat dilihat dari nilai signifikansi yang diperoleh, diketahui nilai signifikansi Net Profit Margin $=0,449$ lebih besar dari $(\alpha)=0,05$ hal ini berari bahwa Net Profit Margin tidak terjadi heterokedastisitas.

6).Earning Pershare

Uji Heterokedastisitas ini dapat dilihat dari nilai signifikansi yang diperoleh, diketahui nilai signifikansi Earning Pershare $=0,957$ lebih besar dari $(\alpha)=0,05$ hal ini berari bahwa Earning Pershare tidak terjadi heterokedastisitas.

\section{b. Uji Multikolinieritas}

Uji Multikolonieritas bertujuan untuk menguji apakah dalam model regresi

ditemukan adanya korelasi antar variabel bebas, serta untuk membuktikan bahwa ketika ketika menggunakan uji residual dalam menguji hipotesis, nilai tolerance dan Variance Inflantion Factor (VIF) yang di dapatkan lebih baik, terjadi tidak terjadi gejala multikolineariras dibandingkan menggunakan uji moderated regression analysis nilai selisih mutlak. Model regresi yang seharusnya tidak terjadi korelasi antara variabel bebas. uji Kolonearitas dilakukan dengan melihat nilai tolerance atau Variance inflantion factor (VIF) dari hasil analisis dengan menggunakan SPSS (Statistical Package social science) for windows versi 19.0 Apabila nilai tolerance lebih tinggi dari 0,10 atau VIF lebih kecil dari 10, maka dapat disimpulkan tidak terjadi gejala multikolinearitas (Ghozali, 2012). 
Tabel 8

Uji Multikolinearitas

Coefficients $^{\mathrm{a}}$

\begin{tabular}{|c|c|c|c|c|}
\hline & \multirow[b]{2}{*}{ Model } & \multirow[b]{2}{*}{ Sig. } & \multicolumn{2}{|c|}{ Collinearity Statistics } \\
\hline & & & Tolerance & VIF \\
\hline \multirow[t]{7}{*}{1} & (Constant) &, 033 & & \\
\hline & CAR & ,742 & ,991 & 1,009 \\
\hline & $\mathrm{CR}$ & ,795 & ,984 & 1,016 \\
\hline & DER &, 885 & ,990 & 1,010 \\
\hline & DAR &, 565 & ,993 & 1,007 \\
\hline & NPM & ,734 & ,990 & 1,010 \\
\hline & EPS &, 509 & ,983 & 1,017 \\
\hline
\end{tabular}

Sumber: hasil Analisis Data dengan SPSS

Indikasi terjadinya Multikolinearitas, jika nilai VIF lebih tinggi dari 0,10 lebih kecil dari 10, dapat disimpulkan tidak terjadi Multikolinearitas, Dari hasil analisis bahwa semua variabel independen dengan nilai VIP menghasilkan nilai lebih tinggi dari 0,10 maka variabel independen secara keseluruhan tidak terjadi Multikolinearitas.

c. Uji Autokorelasi

Uji autokorelasi bertujuan untuk menguji apakah dalam model regresi linier terdapat korelasi antara kesalahan pengganggu pada periode $\mathrm{t}-1$, jika terjadi korelasi, maka menunjukkan ada problem autokorelasi (Sarjono, 2011). Untuk mendekati adanya autokorelasi maka dilakukan uji statistik Durbin- Watson. Petokan angka $D$-W (DurbinWatson) untuk mendeteksi autokorelasi secara umum adalah sebagai berikut:

1) Angka $D$ - $W$ dibawah -2 berarti ada korelasi positif

2) Angka $D-W$ antara -2 sampai $+2=$ tidak ada autokorelasi

3) Angka $D-W$ antara -2 sampai $+2=$ ada korelasi positif Tabel 9.

Berikut disajikan hasil uji autokorelasi pada penelitian ini dapat dilihat pada

Tabel 9

Uji Autokorelasi

\begin{tabular}{|c|c|c|c|}
\hline Model & R & R Square & Durbin- watson \\
\hline 1 &, $127^{\mathrm{a}}$ &, 016 &, 709 \\
\hline
\end{tabular}

Sumber: hasil analisis data dengan spss

Dari perhitungan SPSS 19.0 For Windows diperoleh Nilai Durbin watson sebesar 0,709 dengan demikian dapat disimpulkan hasil analisis tersebut tidak terjadi autokorelasi.

\section{Uji Hipotesis}

Pengujian Hipotesis di gunakan untuk menguji kesesuaian teori dengan hasil regresi. yang didasarkan pada koofisien regresi dengan independen variabel.

\section{Uji Signifikansi Simultan (Uji F)}

Sugiyono, (2011) Uji Simultan dilakukan untuk membuktikan hipotesis terhadap pengaruh variabel bebas secara bersama-sama terhadap variabel terikat.

(1). Kriteria Pengujian:

$\mathrm{F}$ Hitung $>\mathrm{F}$ tabel $=\mathrm{H} 0$ ditolak $/ \operatorname{sig} \mathrm{F}<\alpha 0,05$

$\mathrm{F}$ Hitung $\leq \mathrm{F}$ tabel $=\mathrm{H} 0$ diterima/ sig $\mathrm{F} \geq \alpha 0,05$

(2). Keputusan atau Kesimpulan Pengujian

$\mathrm{H}_{0}$ : Tidak terdapat pengaruh Likuiditas, Solvabilitas, Profitabilitas secara bersama sama terhadap Nilai Perusahaan Pertambangan di Bursa Efek Indonesia. 
$\mathrm{H}_{\mathrm{a}}$ : Terdapat Pengaruh Likuiditas, Solvabilitas, Profitabilitas secara bersama sama terhadap Nilai Perusahaan Pertambangan di Bursa Efek Indonesia.

(3). Keputusan atau kesimpulan pengujian

a) Jika $\mathrm{F}$ Hitung $>\mathrm{F}$ table sig $\mathrm{F}<\alpha(0,05)$, maka $\mathrm{H}_{0}$ ditolak dan $\mathrm{H}_{\mathrm{a}}$ diterima, terdapat pengaruh yang signifikant Likuiditas, Solvabilitas, Profitabilitas secara bersamasama terhadap Nilai Perusahaan Pertambangan di Bursa Efek Indonesia.

b) Jika $\mathrm{F}$ Hitung $\leq \mathrm{F}$ table sig $\mathrm{F} \geq \alpha(0,05)$, maka $\mathrm{H}_{0}$ diterima dan $\mathrm{H}_{\mathrm{a}}$ ditolak, artinya tidak terdapat pengaruh yang signifikant Likuiditas, Solvabilitas, Profitabilitas secara bersama-sama terhadap Nilai Perusahaan Pertambangan di Bursa Efek Indonesia.

Hasil Uji F dapat dilihat pada Tabel 10 sebagai berikut:

\section{Tabel 10}

Hasil Uji F

\begin{tabular}{|c|c|c|c|c|c|c|}
\hline \multicolumn{7}{|c|}{ ANOVA $^{b}$} \\
\hline & Model & Sum of Squares & $\mathrm{df}$ & Mean Square & $\mathrm{F}$ & Sig. \\
\hline 1 & $\begin{array}{l}\text { Regression } \\
\text { Residual } \\
\text { Total }\end{array}$ & $\begin{array}{c}47748,447 \\
2889993,192 \\
2937741,639\end{array}$ & $\begin{array}{c}6 \\
63 \\
69 \\
\end{array}$ & $\begin{array}{c}7958,074 \\
45872,908\end{array}$ &, 173 &, $983^{\mathrm{a}}$ \\
\hline
\end{tabular}

a. Predictors: (Constant), EPS, DAR, CAR, NPM, DER, CR

b. Dependent Variable: NP

Pengujian ini dimaksudkan untuk mengetahui apakah variabel independensecara bersama sama berpengaruh terhadap variabel dependen. Pengujian ini menghasilkan nilai F sebesar 0,173 dengan signifikan sebesar 0,983 nilai ini signifikan pada tingkat signifikansi $\alpha 0,05$. Hal ini berarti $\mathrm{H}_{0}$ diterima dan ${ }_{\mathrm{Ha}}$ ditolak artinya secara bersama sama Variabel independen tidak terdapat pengaruh terhadap variabel dependen.

\section{Uji Koefisien Regresi (Uji T)}

Dalam Penelitian ini uji t untuk menguji variabel bebas satu persatu, apakah ada satu tidak berpengaruh terhadap variabel terikat (Y).

(1). Kriteria Pengujian:

$\mathrm{t}$ Hitung $>\mathrm{t}$ tabel $=\mathrm{H} 0$ ditolak $/ \operatorname{sig} \mathrm{t}<\alpha 0,05$

$\mathrm{t}$ Hitung $\leq \mathrm{t}$ tabel $=\mathrm{H} 0$ diterima/ sig $\mathrm{t} \geq \alpha 0,05$

(2). Keputusan atau Kesimpulan Pengujian

$\mathrm{H}_{0}$ : Tidak terdapat pengaruh Likuiditas, Solvabilitas, Profitabilitas secara bersama sama terhadap Nilai Perusahaan Pertambangan di Bursa Efek Indonesia.

$\mathrm{H}_{\mathrm{a}}$ : Terdapat Pengaruh Likuiditas, Solvabilitas, Profitabilitas secara bersama sama terhadap Nilai Perusahaan Pertambangan di Bursa Efek Indonesia.

(3). Keputusan atau kesimpulan pengujian

a) Jika $\mathrm{t}$ Hitung $>\mathrm{t}$ table sig $\mathrm{t}<\alpha(0,05)$, maka $\mathrm{H}_{0}$ ditolak dan $\mathrm{H}_{\mathrm{a}}$ diterima, terdapat pengaruh yang signifikant Likuiditas, Solvabilitas, Profitabilitas secara bersamasama terhadap Nilai Perusahaan Pertambangan di Bursa Efek Indonesia.

b) Jika $t$ Hitung $\leq t$ table sig $t \geq \alpha(0,05)$, maka $\mathrm{H}_{0}$ diterima dan $\mathrm{H}_{\mathrm{a}}$ ditolak, artinya tidak terdapat pengaruh yang signifikant Likuiditas, Solvabilitas, Profitabilitas secara bersama-sama terhadap Nilai Perusahaan Pertambangan di Bursa Efek Indonesia. Berikut hasil Uji dapat dilihat pada Tabel 11. 
Tabel 11.

Uji Parsial T

\begin{tabular}{|c|c|c|c|c|c|c|}
\hline \multicolumn{7}{|c|}{ Coefficients $^{\mathrm{a}}$} \\
\hline \multirow{2}{*}{\multicolumn{2}{|c|}{ Model }} & \multicolumn{2}{|c|}{ Unstandardized Coefficients } & $\begin{array}{l}\text { Standardized } \\
\text { Coefficients }\end{array}$ & \multirow[b]{2}{*}{$\mathrm{t}$} & \multirow[b]{2}{*}{ Sig. } \\
\hline & & $\mathrm{B}$ & Std. Error & Beta & & \\
\hline 1 & (Constant) & 77,395 & 35,423 & & 2,185 & ,033 \\
\hline & CAR & $-1,146$ & 3,468 &,- 041 &,- 331 & ,742 \\
\hline & $\mathrm{CR}$ & $-1,699$ & 6,523 &,- 033 &,- 260 & ,795 \\
\hline & DER &,- 487 & 3,353 &,- 018 &,- 145 & 885 \\
\hline & DAR & $-7,257$ & 12,536 &,- 073 &,- 579 &, 565 \\
\hline & NPM &,- 236 & ,691 &,- 043 &,- 341 & ,734 \\
\hline & EPS &,- 094 &, 142 &,- 084 &,- 664 &, 509 \\
\hline
\end{tabular}

a). Pengaruh Current Ratio Terhadap Nilai Perusahaan

Uji hipotesis Current Ratio, dilihat dari nilai signifikansi t yang diperoleh, diketahui nilai signifikan Current Ratio 0,742 lebih besar dari nilai $(\alpha)=0,05$ maka variabel Current Ratio X1 tidak berpengaruh signifikan terhadap nilai perusahaan.

b). Pengaruh Cash Ratio Terhadap Nilai Perusahaan

Uji hipotesis Cash Ratio, dilihat dari nilai signifikansi t yang diperoleh, diketahui nilai signifikan Cash Ratio 0,795 lebih besar dari nilai $(\alpha)=0,05$ artinya H0 diterima, maka variabel Cash RatioX2 tidak berpengaruh signifikan terhadap nilai perusahaan.

c). Pengaruh Debt to Equity Ratio Terhadap Nilai Perusahaan

Uji hipotesis Debt to Equity Ratio, dilihat dari nilai signifikansi t yang diperoleh, diketahui nilai signifikan Debt to Equity Ratio 0,795 lebih besar dari nilai $(\alpha)=0,05$ artinya $\mathrm{H} 0$ diterima artinya variabel Debt to Equity RatioX3tidak berpengaruh signifikan terhadap nilai perusahaan.

d). Pengaruh Debt to Asset Ratio Terhadap Nilai Perusahaan

Uji hipotesis Debt to Asset Ratio, dilihat dari nilai signifikansi t yang diperoleh, diketahui nilai signifikan Debt to Asset Ratio 0,565 lebih besar dari nilai $(\alpha)=0,05$ artinya H0 diterima artinya variabel Debt to Asset Ratio X4 tidak berpengaruh signifikan terhadap nilai perusahaan.

e). Pengaruh Net Profit Margin Terhadap Nilai Perusahaan

Uji hipotesis Net Profit Margin, dilihat dari nilai signifikansi t yang diperoleh, diketahui nilai signifikan Net Profit Margin 0,734 lebih besar darinilai $(\alpha)=0,05$ artinya H0 diterima artinya variabel Net Profit Margin X5 tidak berpengaruh signifikan terhadap nilai perusahaan.

f).Pengaruh Net Profit Margin Terhadap Nilai Perusahaan

Uji hipotesis Earning Pershare, dilihat dari nilai signifikansi t yang diperoleh, diketahui nilai signifikan Earning Pershare, 0,509 lebih besar dari nilai $(\alpha)=0,05$ artinya H0 diterima artinya variabel Net Profit Margin X6 tidak berpengaruh signifikan terhadap nilai perusahaan.

\section{Uji Koefisien Determinasi $\left(\mathbf{R}_{2}\right)$}

Uji $R_{2}$ atau Uji Determinasi merupakan suatu ukuran yang penting dalam regresi, karena dapat menginformasikan baik atau tidaknya model regresi yang terestimasi, atau dengan kata lain angka tersebut dapat mengukur seberapa dekatkah garis regresi yang terestimasi dengan data sesungguhnya. Nilai Koefisien Determinasi $\left(R_{2}\right)$ ini mencerminkan seberapa besar variasi dari variabel terikat $\mathrm{Y}$ dapat diterangkan oleh variabel bebas X.

Bila Koefisien determinasi sama dengan $0\left(\mathrm{R}_{2}=0\right)$, artinya variasi dari $\mathrm{Y}$ tidak dapat diterangkan oleh $\mathrm{X}$ sama sekali. Sementara bila $\mathrm{R}_{2}=1$ artinya variasi dari $\mathrm{Y}$ secara keseluruhan dapat diterangkan oleh $X$. Dengan kata lain bila $\mathrm{R}_{2}=1$, maka semua titik penganatan berada tepat pada garis regresi. Dengan demikian baik buruknya suatu persamaan regresi ditentukan oleh $\mathrm{R}_{2}$ nya yang mempunyai nilai antara nol dan satu 
(Priyatno, 2008). Pengaruh Current Ratio (X1), Cash Ratio (X2), Debt To Equity Ratio(X3), Debt To Asset Ratio(X4), Net Profit Margin (X5), Earning Pershare (X6) secara bersama sama terhadap nilai perusahaan (Y) yaitu menggunakan uji koefisien determinan. Berikut ini disajikan hasil uji koefisien determinan dapat dilihat pada Tebel 12.

Tabel 12

Uji Determinasi $\mathbf{R}_{2}$

\begin{tabular}{|c|c|c|c|c|}
\hline Model & R & R Square & Adjusted R Square & $\begin{array}{c}\text { Std.Error of } \\
\text { estimate }\end{array}$ \\
\hline 1 &, $127^{\mathrm{a}}$ &, 016 &,- 709 & 214,17962 \\
\hline
\end{tabular}

Dari Tabel 12 diatas diperoleh nilai koefisien determinasi $R_{2}$ sebesar 0,016, artinya variasi dari variabel $\mathrm{Y}$ tidak dapat diterangkan oleh variabel $\mathrm{X}$ sama sekali.

\section{PEMBAHASAN HASIL PENELITIAN}

Berdasarkan pada uji hipotesis $\mathrm{F}$ dihasilkan nilai signifikan untuk variable Current Rasio (X1), Cash Rasio (X2), Debt To Asset Ratio (X3), Debt To Equity Ratio (X4), Net Profit Margin X5),Earning Pershare X6) pada perusahaan Pertambangan Bursa Efek Indonesia menunjukkan pengaruh yang signifikan secara bersama-sama terhadap nilai perusahaaan. Secara parsial berdasarkan pembuktian hipotesis dari persamaan regresi dapat dijelaskan sebagai berikut :

\section{Pengaruh Current Ratio (X1) terhadap Nilai Perusahaan.}

Berdasarkan hasil analisis data SPSS yang diperoleh nilai koofisien regresi Current Ratio terhadap nilai perusahaan adalah sebesar 0,033 berarti Current Ratio tidak berpengaruh positif terhadap nilai perusahaan, nilai signifikan (Sig t) sebesar 0.033 yang berarti sig t $(0,033) \geq \alpha(0,05)$. Dalam hal ini menunjukkan bahwa variable Current Ratio tidak berpengaruh secara parsial terhadap nilai perusahaan.

Hasil penelitian ini mempunyai perbedaan yang dilakukan oleh Corry Winda Anzlina (2013). Berdasarkan hasil uji T dan hasil uji F pada $5 \%$ tingkat signifikan hasil menunjukkan bahwa Current Ratio secara parsial berpengaruh signifikan terhadap nilai perusahaan. Perubahan yang ditunjukkan oleh Current Ratio terhadap nilai perusahaan akan diikuti oleh peningkatan atau penurunan nilai perusahaan.

\section{Pengaruh Cash Ratio (X2) Terhadap Nilai Perusahaan}

Berdasarkan hasil analisis data SPSS yang diperoleh nilai koofisien regresi Cash Ratio terhadap nilai perusahaan adalah sebesar 0,795 berarti Cash Ratio tidak berpengaruh terhadap nilai perusahaan, nilai signifikan (Sig t) sebesar 0.033 yang berarti sig t $(0,795) \geq \alpha(0,05)$. Dalam hal ini menunjukkan bahwa variable Cash Ratiotidak berpengaruh secara parsial terhadap nilai perusahaan.

Hasil penelitian yang berbeda dengan hasil penelitian yang dilakukan oleh Gisela P. Rompas (2013), yang menyatakan Cash Ratio secara bersama-sama berperngaruh terhadap nilai perusahaan. Dalam hal ini Cash Ratio ditunjukkan besar kecilnya asset lancar yang dapat memenuhi kewajiban jangka pendek.

\section{Pengaruh Debt To Equity Ratio (X3) Terhadap Nilai Perusahaan}

Berdasarkan hasil analisis data SPSS yang diperoleh nilai koofisien regresi Debt

To Equity Ratio terhadap nilai perusahaan adalah sebesar 0,795 berarti Debt To Equity Ratio tidak berpengaruh positif terhadap nilai perusahaan, nilai signifikan (Sig t) sebesar 0.005 yang berarti sig t $(0,885)=\alpha(0,05)$. Dalam hal ini menunjukkan bahwa variable Debt To Equity Ratio tidak berpengaruh secara persial terhadap nilai perusahaan.

Hasil penelitian ini sama dengan hasil penelitian yang dilakukan oleh Eva (2010), yang menyatakan bahwa DER tidak berpengaruh signifikan terhadap nilai perusahaan. 
Hubungan positif antara Debt To Equity Ratio (DER) dengan nilai perusahaan disebabkan karena diketahui. Hal ini bahwa perusahaan pertambangan menggunakan hutangnya lebih kecil dari modal sendiri. Debt To Equity Ratio (DER) Ratio ini digunakan untuk mengukur keseimbangan proporsi antara asset yang didanai oleh kreditor (hutang) dan didanai oleh pemilik perusahaan (equity). Jika rasio ini cukup tinggi, maka hal tersebut menunjukkan tingginya penggunaan hutang, sehingga perusahaan dengan mudah mengalami kesulitan dan memiliki resiko yang besar dan menyebabkan kebangkrutan pada perusahaan.

\section{Pengaruh Debt To Aset Ratio (X4) terhadap Nilai Perusahaan}

Berdasarkan hasil analisis data SPSS yang diperoleh nilai koofisien regresi Debt To Aset Ratio terhadap nilai perusahaan adalah sebesar 0,565 berarti Debt To Aset Ratio berpengaruh negatif terhadap nilai perusahaan, nilai signifikan (Sig t) sebesar 0.565yang berarti sig t $(0,565) \geq \alpha(0,05)$. Dalam hal ini menunjukkan bahwa variable Debt To Aset Ratio tidak berpengaruh secara persial terhadap nilai perusahaan.

Hasil penelitian yang berbeda dengan hasil penelitian yang dilakukan oleh Gisela P. Rompas (2013), yang menyatakan Debt To Aset Ratio secara bersama-sama berpengaruh terhadap nilai perusahaan. Dalam hal ini Debt To Aset Ratio memiliki kemampuan dalam memenuhi kewajiban dan menutupi semua hutangnya pada saat perusahaan dilikuidasi.

\section{Pengaruh Net Profit Margin (X5) terhadap Nilai Perusahaan}

Berdasarkan hasil analisis data SPSS yang diperoleh nilai koofisien regresi Net Profit Margin terhadap nilai perusahaanadalah sebesar 0,734 berarti Net Profit Margin berpengaruh negatif terhadap nilai perusahaan, nilai signifikan (Sig t) sebesar 0.734 yang berarti sig t $(0,734) \geq \alpha(0,05)$. dalam hal ini menunjukkan bahwa variable Net Profit Margin tidak berpengaruh secara persial terhadap nilai perusahaan.

Hasil Penelitian yang berbeda dengan hasil penelitian yang dilakukan oleh Gisela P.Rompas (2013), yang menyatakan Net Profit Margin secara bersama-sama berpengaruh terhadap nilai perusahaan. Dalam hal ini Net Profit Margin yang tinggi menandakan kemapuan perusahaan menghasilkan laba yang tinggi pada tingkat penjualan tertentu. Net Profit Margin yang rendah menandakan penjualan yang terlalu rendah untuk tingkat biaya tertentu, atau biaya yang terlalu tinggi untuk tingkat penjualan tertentu, dari kedua hal tersebut secara umum rasio yang rendah bias menunjukkan ketidak efisien manajemen.

\section{Pengaruh Earning Pershare (X6) terhadap Nilai Perusahaan}

Berdasarkan hasil analisis data SPSS yang diperoleh nilai koofisien regresi Net Profit Margin terhadap nilai perusahaan adalah sebesar 0,509 berarti Net Profit Margin berpengaruh terhadap nilai perusahaan, nilai signifikan (Sig t) sebesar 0,509 yang berarti sig $\mathrm{t}(0,509) \leq \alpha(0,05)$. Dalam hal ini menunjukkan bahwa variable Earning Persharetidak berpengaruh secara positif terhadap nilai perusahaan.

Hasil penelitian ini juga berpengaruh sesuai dengan hasil penelitian yang dilakukan Corry winda Anzlina (2013) meneliti tingkat Likuiditas, Solvabilitas, Aktivitas dan Profitabilitas terhadap nilai perusahaan pada perusahaan real estate dan proferty dibursa Efek Indonesia. Berdasarkan hasil uji $\mathrm{F}$ secara bersama-sama berpengaruh terhadap nilai perusahaan dan hasil uji t secara parsial terdapat masing-masing variable independen berpengaruhterhadap variable defenden. Dalam hal ini setiap kenaikan Earning Pershareakan di ikuti dengan peningkatan nilai pada perusahaan.

\section{IMPLIKASI}

Penulis akan menyebarkan implikasi dari hasil penelitian dan hasil temuan dilapangan bagi pihak yang terkait sebagai berikut :

1. Sebaiknya pihak perusahaan bisa mempertahankan dan meningkatkan kemampuan suatu perusahaan dalam membayar kewajiban jangka pendeknya saat 
jatuh tempo yang segera dipenuhi, karena dengan adanya kemampuan perusahaan memenuhi kewajiban tersebut, dapat menjadikan kepercayaan kreditor terhadap perusahaan. Semakin tinggi likuiditas semakin percaya para kreditor terhadap perusahaan dalam memenuhi kewajiban yang segera dipenuhi. Hasil sig (t) 0,588 yang berarti (sig t) $0,588 \geq(0,05)$ dan Cash Ratio sig (t) 0,406 yang berarti (sig t) $0,406 \geq(0,05)$ hal ini dapat disimpulkan Current Ratio dan Cash Ratio tidak berpengaruh terhadap nilai perusahaan.

2. Pihak perusahaan harus mampu mempertahankan kemampuan perusahaan dalam memenuhi kewajiban pada saat perusahaan tersebut dilikuidasi, Debt To Equity Ratio menunjukkan hasil sif (t) 0,862 yang berarti (sig t) $0,862 \geq(0,05)$ dan Debt To Asset Ratio menunjukkan hasil sig (t) 0,155 yang berarti (sig t) $0,155 \geq(0,05)$ hal ini dapat disimpulkan Debt To Equity Ratio dan Debt To Asset Rasio tidak berpengaruh terhadap nilai perusahaan.

3. Kemampuan perusahaan dalam menghasilkan laba yang tinggi pada tingkat penjualan tertentu untuk perlu di tingkatkan, karena net profit margin yang rendah menandakan penjualan yang rendah untuk tingkat biaya tertentu dan hal tersebut menunjukkan ketidakefisiennya manajemen. Dari hasil penelitian signifikan (sig t) 0,449 yang berarti (sig t) $0,449 \geq \alpha(0,05)$ hal ini dapat disimpulkan bahwa debt to equity ratio tidak berpengaruh terhadap nilai perusahaan. Dilihat dari nilai yang signifikan (sig t) 0,957 yang berarti (sig t) $0,957 \geq \alpha(0,05)$. Hal ini dapat disimpulkan Earning Pershare tidak berpengaruh terhadap nilai perusahaan.

\section{SIMPULAN DAN SARAN}

\section{Simpulan}

Berdasarkan analisis hasil penelitian dan pembahasan mengenai mengetahui pengaruh likuiditas yang diukur dengan Current Ratio, Cash Ratio Solvabilitas diukur dengan Debt To Equity Ratio dan Debt To Aset Ratio, profitabilitas diukur dengan Net Profit Margin dan Earning Pershare terhadap nilai perusahaan Pertambangan yang terdaftar di BEI selama periode tahun 2009-2013, maka penelitian menyimpulkan:

1. Dari hasil penguji hipotesis secara (Simultan) terdapat pengaruh yang signifikan secara bersama sama variable bebas yang diukur dengan Current Ratio, Cash Ratio, Debt To Equity Ratio, Debt To Aset Rasio, Net Profit Margin, Earning Pershare terhadap Nilai Perusahaan pada perusahaan pertambangan Bursa Efek Indonesia.

2. Hasil penguji hipotesis secara parsial bahwa dari keenam variable tersebut, variable Current Ratio, Cash Ratio, variable Debt to Equity Ratio dan Debt to Aset Ratio, Net Profit Margin dan Earning Pershare tidak berpengaruh secara signifikan terhadap variable terikat yaitu nilai perusahaan. Artinya informasi dari rasio-rasio tersebut belum sepenuhnya membantu investor dalam membuat keputusan investasinya. Hasil penelitian memiliki perbedaan dengan penelitian terdahulu dikarenakan perbedaan waktu dan keterbatasan sektor perusahaan yang dijadikan sampel.

\section{Saran}

Berdasarkan simpulan diatas, maka rekomendasi yang dapat diberikan melalui hasil penelitian adalah sebagai berikut:

1. Bagi manajemen, untuk meningkatkan kepercayaan pemegang saham perusahaan, maka perusahaan harus mampu menunjukkan kinerja perusahaan yang baik melalui tingkat current ratio yang baik dan menyampaikan informasi yang cukup kepada investor mengenai perkembangan perusahaan.

2. Bagi investor, agar melakukan analisis-analisis terhadap rasio keungan terutama terhadap rasio yang berpengaruh terhadap nilai perusahaan sebelum melakukan investasi dalam suatu perusahaan. 
3. Bagi peneliti selanjutnya, agar menggunakan sampel yang lebih beragam, memperpanjang periode penelitian, dan dapat menambah variabel-variabel yang digunakan sehingga hasil yang diperoleh dapat lebih akurat.

\section{DAFTAR PUSTAKA}

Brigham, Eugene Dan Houston. 2006. Manajemen Keuangan Buku 2, Edisi Kedelapan. Alih Bahasa Suharto Dan Dodo, Jakarta: Erlangga.

Cooper, D. dan Schindler, P.S. 2006. Metode Riset Bisnis, Edisi Sembilan. Volume 1 (Budijanto, dkk., Penterjemah). Jakarta: PT Media Global Edukasi.

Corry Winda, Anzlina. 2013. Pengaruh Tingkat Likuiditas, Solvabilitas, Aktivitas, Dan Profitabilitas Terhadap Nilai Perusahaan. Jurnal Ekonom, Vol 16, No2, April 2013.

Eva Eko Hidayati 2010. Analisis Pengaruh DER, DPR, ROE Dan Size Terhadap BPV Perusahaan Manufaktur Listing BEI Periode 2005-2007. Universitas Diponorogo. Online, (Http://Eprints,Undip.Ac.Id/24064/Eva Eko Hidayati).

Ganto, J., Khadafi, M., Albra, W., Dan Syamni, G. 2008. Pengaruh Kinerja Keuangan Perusahaan Manufaktur Terhadap Return Saham Di Bursa Efek Indonesia. Media Riset Akuntasi, Auditing Dan Informasi. Vol:8 No.1 Hal. 85-96.

Ghozali, 1. 2012. Aplikasi Analisis Multivariate Dengan Program IBM SPSS 20. Edisi 6. Semarang: Badan Penerbit Universitas Diponegoro.

Gisela P Rompas, 2013 Likuiditas, Solvabilitas, Rehabilitas Terhadap Nilai Perusahaan. Journal EMBA Manajemen Vol.1 No.3 September 2013 Hal.252-256

Indonesia Capitan Market Directory.2012.

--------. 2014.

Jogiyanto,2010. Teori Portofolio Dan Analisis Investasi. Edisi 7. Yogyakarta: BPFE.

Kasmir, 2012. Analisis Laporan Keuangan, Raja Grafindo Persada, Jakarta.

Kuswandi, 2005. Meningkatkan Laba Melalui Pendekatan Akuntasi Keuanagan Dan Akuntasi Biaya. Jakarta: Pt. Alex Media Komputindo.

Mahendra, Alfharedo Dj.2012 Pengaruh Kinerja Keuangan Terhadap Nilai Perusahaan (Kebijakan Dividen Sebagai Variabel Moderating) Pada Perusahaan Manufaktur BEI Pascasarjana Universitas Udayana Denpasar.

Mahendra, A., Artini, dan Suarjaya. 2012. Pengaruh Kinerja Keuangan terhadap Nilai Perusahaan pada Perusahaan Manufaktur di Bursa Efek Indonesia. Jurnal Manajemen, Strategi Bisnis, dan Kewirausahaan. Vol: 6. No. 2. hal 130138.

Salvatore, Dominick. 2005. Ekonomi Manajerial dalam Perekonomian Global. Salemba Empat: Jakarta. Schoubben, F., dan C. Van Hulle. 2004.” The Determinant of Leverage: Difference beetwen Quoted and Non Quote Firms", Tijdschrift voor Economie en Management, XLIX (4): 589-621.

Sugiyono. 2009. Statistik Untuk Penelitian. Bandung: Alfabeta

--------. 2011. Statistik Untuk Penelitian. Bandung: Alfabeta

Sutrisno, Manajemen Keuangan: Teori Konsep dan Aplikasi Edisi Pertama. Ekonisia: Yogyakarta.

Sugiyono. 2009. Statistik Untuk Penelitian. Bandung: Alfabeta

Van Horne, James C dan John wachowicz. 2007. Prinsip prinsip manajemen keuangan. Buku 2. Edisi 12. Alih bahasa oleh dewi fitrisari dan D Arnos. Jakarta: Salemba Empat. 